\title{
Evaluation of performance and metabolism of dairy cows fed pea seeds (Pisum sativum) with different anti-nutritional content
}

\begin{abstract}
The aim of this study is to determine the effect produced by selected pea cultivars with different anti-nutritional content on dairy cows' metabolism. In the current ninety-day present, 32 dairy cows were divided into four groups (Z, G, GU and C). Three experimental groups (Z, G and GU) were fed a production mixture consisting of $25 \%$ pea seeds and the following: ( $\mathrm{Z}$ - Zekon cultivar with low anti-nutritional content; G - Gotik cultivar with high antinutritional content; and GU - Gotik cultivar whose anti-nutritional content was reduced technologically). The control group was fed the production mixture with a higher proportion of extracted soybean meal and grain meal. Feeding rations were balanced to have an analogical composition of crude protein and energy. Feeding the pea supplement did not affect energy metabolism of the dairy cows. As for nitrogen metabolism, group $\mathrm{Z}$ showed higher concentrations of ammonia in rumen fluid and urea in blood compared to groups GU and C. No animal from the experimental groups showed reduced intake of feed. An insignificantly lower performance was noted (daily milk yield, protein production and lactose production) in group G. Overall, better results were observed in group Z. On the basis of the current study, peas can be used as an alternative source of proteins and energy in the diet of dairy cattle.
\end{abstract}

Key Words: pea, dairy, metabolism, milk production

\section{Zusammenfassung}

Titel der Arbeit: Bewertung der Produktivität und des Stoffwechsels bei Milchkühen, gefüttert mit Erbsensorten unterschiedlichen antinutritiven Stoffinhalts

Zweck dieses Experimentes war es, den Einfluss verschiedener Erbsensorten mit unterschiedlichem Inhalt an antinutritiven Inhaltsstoffen im Produktionsfuttergemisch auf den Stoffwechsel und die Leistung der Milchkuh zu beurteilen. Im neunzigtägigen Experiment wurden 32 Milchkühe betrachtet, die in 4 Gruppen (C, Z, G, GU) aufgeteilt wurden. Die Futterrationen wurden gemäß dem Rohprotein (N - haltige Inhaltstoffe) und Energieinhalt ausbalanciert. Die Milchkühe aus den Experimentgruppen (Z, G, GU) bekamen Leistungsfutter mit einem 25\%-igen Anteil an Erbsen ( $\mathrm{Z}$ - die Sorte Zekon mit einem niedrigen Inhalt an antinutritiven Stoffen, G - die Sorte Gotik mit einem hohen Inhalt an antinutritiven Stoffen, GU - die Sorte Gotik - nach einer den Inhalt an antinutritiven Stoffen reduzierenden technologischen Bearbeitung). Die Verfütterung der Erbsen beeinflusste den energetischen Metabolismus keineswegs. Im Vergleich zu den Gruppen GU und K wurde aus dem Rohproteinstoffwechsel in der Gruppe Z ein höherer Inhalt an Ammoniak im Pansensaft und Harnstoff im Blut festgestellt. In keiner der Experimentgruppen traten reduzierte Futteraufnahmen auf. Aus der Sicht des Einflusses auf die Milchleistung wurde keine signifikante Reduzierung in der Gruppe $\mathrm{G}$ und eine gewisse Tendenz zu besseren Ergebnissen in der Gruppe Z beobachtet. Auf Grund des durchgeführten Experimentes ist die Verfütterung der Erbsen als eine Protein- und Energiequelle zu empfehlen. 


\section{Introduction}

A steadily growing volume of milk production on dairy cattle farms has increased demands of dairy cows in terms of their nutrient intake. Dairy cattle farms often cope with negative energy balance that negatively affects production rates and increases the risk of impaired fertility of dairy cows (STAUFENBIEL et al., 2003; GABEL and VOIGT, 2000). Besides sufficient content of energy in feeding ration, high productivity of dairy cows is based also on sufficient intake of crude protein with high content of quality protein. Traditionally, these nutrients have been supplied by extracted soybean meal. However, as its prices continually fluctuate, it poses a financial burden for farmers. In feeding mixtures, soya can be replaced by pulses belonging to traditional European agricultural commodities. Pea is one of the pulses that are today less used in feeding rations of dairy cows. Pea seeds are source of high-quality protein whose values reach, on average, 20-25\% of the dry matter content (LALLES 1993). Total protein values of pea are lower than those of soybean meal (24\% vs. $51.6 \%$ ). Pea protein is typical of high protein degradability in rumen (around 90\%) and low values of "by-pass" protein that passes through the rumen undigested to small intestine (MUSTAFA et al. 1998). The effect of dietary proteins of diverse rumen degradability was also evaluated according to the efficiency of metabolizable energy (ME) utilization by calves at the growth and maintenance levels of feeding. No significant influence was noted of the difference in degradability of protein source in a diet on efficiency of ME utilization at growth level. The efficiency of ME utilization for maintenance, however, was affected by a difference in degradability of protein sources in a diet (SEKINE et al., 2004).

The use of peas in the fodder industry has been hindered by conservative approaches, which are concerned about the effect of anti-nutritional substances contained in pulses. The following anti-nutritional substances are contained in peas (listed in order of significance): trypsin inhibitors, lectins (phytohemaglutinins), flatulent oligosaccharides, gallic acid and other substances from the phenolic group or substances with phytoestrogenic effects. Still, these substances play a significant role in plant protection. In fact, elimination of these substances by means of breeding may lead to higher susceptibility of plants to pests and diseases, resulting in reduction of yield. Peas can also be technologically engineered to reduce anti-nutritional content. The most common technological treatment of peas is based on high temperatures and pressure (extrusion), which reduce anti-nutritional content and increase the amount of undegradable protein (LOSAND et al., 2003; GOELEMA et al. 1998; PETIT et al. 1997). BENCHAAR et al. (1994) found that heat-treated peas improve availability of amino acids in the small intestine. In 2003, a treatment method reducing peas anti-nutritional content was established (DVORAK et al., 2005). This study also monitored dairy cows fed the peas treated in this way.

The aim of the study was to evaluate the metabolism and performance of dairy cows that were fed production-feeding mixtures consisting of selected cultivars of peas with different anti-nutritional content, as well as peas treated by the above-mentioned method. The cows were monitored during 90 days of their lactation period. 


\section{Materials and methods}

Monitoring was performed on a farm of high-milk-yield dairy cows, crossbred with Holstein in eastern Bohemia. The milk cows were stabled in a four-row tie-up barn for 200 cows. The average farm milk yield amounted to 6500 litres. Thirty two dairy cows were selected for the experiment, divided on the principle of analogous tetrads according to breed, age and efficiency to the three experimental groups (Z, G, GU) and one control group (C). All dairy cows were fed on the same basic feeding ratio consisting of bulky fodder (14 kg of maize silage, $5 \mathrm{~kg}$ of beet pulp silage, $1 \mathrm{~kg}$ of meadow hay and $1.5 \mathrm{~kg}$ of wet maize - CCM) and production mixtures that were balanced to have an analogical composition of crude protein and energy. The experimental groups were fed the production mixture containing 25\% pea seeds: group $\mathrm{Z}$ was fed the Zekon cultivar with low anti-nutritional content; Gotik cultivar with high anti-nutritional content was fed to group G; and group GU was fed the Gotik cultivar whose anti-nutritional content was reduced technologically. The control group was fed the production mixture with higher proportion of extracted soybean meal and grain meal. The nutritional composition of feeding ration required for 30 litre milk yield in the control and experimental groups is described in Table 1.

Table 1

Nutritional composition of diets for control and experimental groups at expected milk yield of 30 litres (8 $\mathrm{kg}$ of production mixture).

(Nährstoffzusammensetzung der Futterration der Milchkühe der Kontrollgruppe und der Experimentgruppen für die Milchleistung $30 \mathrm{l}$ Milch / d (Leistungsfutterportion 8kg).)

\begin{tabular}{|c|c|c|c|}
\hline & & Experimental groups & Control group \\
\hline Dry matter & $\mathrm{g}$ & 19203.90 & 19558.70 \\
\hline Crude protein & g & 3154.91 & 3167.51 \\
\hline PDIA & g & 892.80 & 894.52 \\
\hline PDIN & g & 2054.42 & 2061.93 \\
\hline PDIE & g & 1820.03 & 1842.78 \\
\hline Fat & g & 528.84 & 561.27 \\
\hline Fibre & g & 2832.70 & 2903.56 \\
\hline Starch & $\mathrm{g}$ & 4633.42 & 2612.60 \\
\hline NEL & MJ & 121.34 & 123.37 \\
\hline Calcium & g & 166.57 & 165.86 \\
\hline Phosphorus & g & 81.49 & 89.73 \\
\hline Sodium & g & 45.39 & 46.65 \\
\hline Potassium & $\begin{array}{l}\text { g } \\
\text { g }\end{array}$ & 228.84 & 222.74 \\
\hline Magnesium & $\mathrm{g}$ & 56.526 & 58.31 \\
\hline Copper & $\mathrm{mg}$ & 513.42 & 518.03 \\
\hline Manganese & $\mathrm{mg}$ & 1460.24 & 1540.86 \\
\hline Zinc & $\mathrm{mg}$ & 1989.26 & 2004.18 \\
\hline Selenium & $\mathrm{mg}$ & 10.02 & 9.94 \\
\hline Vitamin A & i.u. & 200001 & 199525 \\
\hline Vitamin D & i.u. & 40000 & 39905 \\
\hline Tocopherol & $\mathrm{mg}$ & 705.76 & 657.55 \\
\hline
\end{tabular}

Nutrient calculation is based on tabular values determined for peas. Actual nutritional contents of individual types of peas are stated in Table 2. The composition of production mixtures for the control and experimental groups is detailed in Table 3. 
Feeding procedures were similar for all groups. Mixtures were supplied to troughs according to the level of expected milk yield, starting with milk yield guaranteed by bulky fodder (10 litres) in a ratio of $400 \mathrm{~g}$ per 1 litre of milk. The expected milk yield of 30 litres was then ensured by $8 \mathrm{~kg}$ of the mixture. The maximum mixture ratio was $10 \mathrm{~kg}$ per cow per day. Changes to the experimental production mixture were done gradually in the course of 5 days.

Table 2

Nutritional composition of actual types of peas on the basis of analyses of their original mass. (Nährstoffzusammensetzung der verwendeten Erbsensorten aufgrund der Analyse der Originalmasse).

\begin{tabular}{lllll}
\hline & & Zekon & Gotik & Gotik modified \\
\hline Dry matter & $\mathrm{g}$ & 872.74 & 869.1 & 887.9 \\
Crude protein & $\mathrm{g}$ & 201.58 & 202.9 & 203.7 \\
PDIA & $\mathrm{g}$ & 24.12 & 21.65 & 24.37 \\
PDIN & $\mathrm{g}$ & 122.19 & 109.67 & 123.45 \\
PDIE & $\mathrm{g}$ & 86.84 & 84.85 & 83.61 \\
Fat & $\mathrm{g}$ & 11.10 & 11.3 & 29.6 \\
Fibre & $\mathrm{g}$ & 58.41 & 48.2 & 62.4 \\
Starch & $\mathrm{g}$ & 70.33 & 70.65 & 69.92 \\
NEL & MJ & 6.97 & 7.02 & 6.95 \\
Ash & $\mathrm{g}$ & 28.2 & 27.7 & 58.5 \\
Calcium & $\mathrm{g}$ & 1.83 & 1.03 & 12.5 \\
Phosphorus & $\mathrm{g}$ & 3.92 & 3.90 & 4.86 \\
Sodium & $\mathrm{g}$ & 0.49 & 0.20 & 0.54 \\
Potassium & $\mathrm{g}$ & 10.14 & 10.3 & 11.1 \\
Magnesium & $\mathrm{g}$ & 1.54 & 1.32 & 1.82 \\
Trypsin inhibitors & TIU & 5.47 & 15.39 & 2.50 \\
\hline
\end{tabular}

Table 3

Composition of production mixture for control and experimental groups.

(Leistungsfuttergemischrezeptur für Milchkühe der Kontrollgruppe und der Experimentgruppen).

\begin{tabular}{lcc}
\hline Raw material & Experimental groups (\%) & Control group (\%) \\
\hline Wheat & 4.0 & 13.0 \\
Barley & 11.5 & 10.0 \\
Triticale & 5.0 & 12.0 \\
Pea seed & 25.0 & - \\
Flax + oat meal (48 \%) & 4.0 & 4.0 \\
Wheat bran & 5.0 & 10.0 \\
Extracted soybean meal & 15.5 & 21.0 \\
Proenergol & 10.0 & 10.0 \\
Feeding limestone & 1.5 & 1.5 \\
Acid sodium carbonate & 1.0 & 1.0 \\
Barley malt culms & 15.0 & 15.0 \\
Mineral supplementary mixture & 2.5 & 2.5 \\
\hline
\end{tabular}

The metabolism of dairy cows was examined via regular blood and rumen fluid samples. The first samples were drawn at the beginning of the experiment. Other samples were collected at the end of weeks 4, 8 and 12. Blood was collected into single-use tubes by puncturing the $v$. jugularis. The tubes were free of any anti-coagulant in order to obtain blood serum. Glucose test samples were preserved by sodium fluoride. The following parameters were determined for the blood serum: total protein (TP), urea (U), total 
bilirubin (Bil), $\gamma$-glutamyl-transferase (GMT), creatine kinase (CK), triacylglyceroles (TG), nonesterified fatty acids (NEFA), $\beta$-hydroxybutyrate (BHB). Glucose (Glu) was measured in fluoride blood plasma.

The values for parameters were determined by photometric methods using an automatic analyzer Cobas Mira (Roche, Switzerland) and the following tests: total bilirubin (BIL 100, Cat. No. 1105309), TG (TGL 4x100, Cat. No. 1312983), GMT (GMT KIN 100, Cat. No. 1302082), U (Urea UV KIN 4 x 50 test, Cat. No. 1307017), CK (CK NAC 7 x 15, Cat. No. 1303801) all supplied by LACHEMA; Glu ( ${ }^{\mathrm{L} G l u k o s a, ~ C a t . ~ N o . ~ 11601), ~ T P ~}$ ( ${ }^{\mathrm{L}}$ Protein total, Cat.No.12751) supplied by DPC Czech; NEFA (NEFA, Cat. No. FA 115), BHB (RANBUT, Cat. No, RB 1008) supplied by RANDOX.

Rumen fluid was collected perorally with the help of a rumen probe and suction. Samples were preserved by toluene in order to determine volatile fatty acids, by formaldehyde to determine infusoria and by mercuric chloride for other parameters. Volatile fatty acids (VFA) were determined by gas chromatography.

The total duration of the experiment was 90 days of lactation. Evaluation of milk- yield was carried out based on results of the monthly milk yield control, while evaluation of reproduction was performed using the data supplied by the farm livestock specialist.

The results were statistically evaluated using F-test to evaluate variation in individual files and, depending on the result, by Student t-test for files with equal/unequal variations. If variances between groups were different according to $F$ test $(p<0.05)$, the $T$ test for files with unequal variation was used. If the variation between groups was coinciding ( $>0.05$ ), the $\mathrm{T}$ test for equal variation was used. The evaluation was performed using Microsoft EXCEL software (MS-Excel@).

\section{Results and discussion}

Evaluation of feed intake and metabolism of dairy cows

The feeding mixture contained $25 \%$ peas. It follows that when fed the maximum ration of $10 \mathrm{~kg}$, cows were given $2.5 \mathrm{~kg}$ of peas per day. Although there were some slight differences between individual cows, no problems were observed when fed the maximum ration. No differences in feed intake were observed between individual experimental groups or between experimental groups and control group. VALENTINE and BARTSCH (1987) and MESSMAN et al. (1992) reported a positive effect of peas on the overall intake of dry mass in dairy cows; similar results were found by REED et al. (2004) in bulls. LOSAND et al. (2003) recommend feeding no more than 4,0 kg of peas per day and one dairy cow. The daily pea ration used in experiment was in accordance with results of ROTHMAIER and KIRCHGESSNER (1990), who recommend feeding no more than 3 $\mathrm{kg}$ of peas per one dairy cow and $1.5 \mathrm{~kg}$ per one bull. In the present study blood and rumen fluid samples were taken regularly in order to evaluate the dairy cows' metabolism in detail.

The results of biochemical examination indicated no alterations of dairy cows' metabolism associated with a pea diet. The parameters of nitrogen metabolism are stated in Table 4. Of nitrogen metabolism, there was concentration of protein analysed and concentration of urea in blood. Significant differences were found between cows fed the 
Zekon cultivar and cows in group GU and C. The animals of the former group showed higher blood concentration of urea as well as higher concentration of ammonia in rumen fluid (physiological values: urea $3.0-5.0 \mathrm{mmol} / \mathrm{l}$, ammonia in rumen fluid: $4-12$ mmol/l; VRZGULA et al., 1990). These results are linked to a higher concentration of degradable crude protein in Zekon cultivar. Blood and rumen fluid values tended to rise in group $\mathrm{G}$ as well. Similar results were also reported by VALENTINE and BARTSCH (1987), who observed increased levels of ammoniacal nitrogen in rumen and subsequently intensified synthesis of bacterial protein in dairy cows fed the peas instead of cereal diets. Also, MUSTAFA et al. (1998) found higher concentrations of plasmatic urea in dairy cows fed pulse seed mixtures (including peas) when compared to dairy cows fed only barley. The parameters analysed in rumen fluid of dairy cows are shown in Table 7. Significant differences were found in the decrease of ammonia values in rumen fluid of group GU in comparison with group $\mathrm{Z}$ in the present study. This may be due to a reduction of degradability of crude protein through technological treatment of peas, which was confirmed in other experiments (unpublished dates). Surprisingly, there were no significant differences found in groups $\mathrm{G}$ and $\mathrm{GU}$ in this experiment. The effect of heat treatment on degradability of crude protein was also verified by GOELEMA et al. (1998), who found a significant increase of undegraded protein content in an extruded pea diet. BENCHAAR et al. (1994) reported improved availability of amino acids in the small intestine in heat-treated beans compared to untreated bean ones. Unlike other researchers, PETIT et al. (1997) did not observed any significant decrease of degradable protein content in dairy cows fed the extruded peas (though they found increased degradability of starch). In contrast to soya or untreated peas, an extruded pea diet led to better digestibility of dry mass and crude protein. Because peas contain a large amount of starches and thus represent a significant source of energy (DAVEBY and AMAN, 1993), their effect on energy metabolism was also monitored (table 5). Initially, lower plasmatic concentrations of glucose were observed in group GU (physiological values 2.2 - 3.3 $\mathrm{mmol} / \mathrm{l}$; VRZGULA et al., 1990). Throughout the experiment no differences between groups were noted. During the study, no ketoses or significant increase of body fat mobilisation was revealed in dairy cows. There was a sign of improving liver functions (Table 5 and 6). During the first month, all groups showed low concentrations of triacylgylcerols in blood serum, which were gradually increasing $\left(0.2 \mathrm{mmol}^{-1}{ }^{-1}\right.$ at week 8 and more than $0.3 \mathrm{mmol}^{-1}$ at week 12) (physiological values $0.2-0.8 \mathrm{mmol} / \mathrm{l}$; VRZGULA et al., 1990). During the experiment, levels of nonesterified fatty acids reached in all three groups physiological values $(0.1-0.35 \mathrm{mmol} / \mathrm{l}$; VRZGULA et al., 1990). In group $G$, slightly decreasing tendency in the second half of the experiment was observed. Dairy cows did not show increased mobilization of lipids or increased values of keto-substances in serum. Beta-hydroxybutyrate levels reached the upper limit of physiological values $(<0.6 \mathrm{mmol} / \mathrm{l}$; KRAFT - DÜRR, 1999). At the beginning of the experiment, bilirubin values were in all groups slightly above the physiological range (0.17 - $5.13 \mu \mathrm{kat} / \mathrm{l}$; VRZGULA et al., 1990) (Table 6). Later on, bilirubin levels decreased (3 - $4 \mu \mathrm{kat} / \mathrm{l})$. Serum levels of $\gamma$-glutamyl-transferase (GMT) did not increase during the experiment which would indicate liver damage. GMT levels reached the upper limit of physiological values $(0.2-0.5 \mu \mathrm{kat} / \mathrm{l}$; VRZGULA et al., 1990). As there were no 
differences between individual groups, this increase was not caused by experimental mixtures we tested but another ingredient of feeding ration (probably it was due to a lower quality of some bulky fodders). GMT activity cannot indicate hepatic steatosis associated with impaired energy metabolism (KALAITZAKIS et al. 2007; PECHOVÁ et al. 1997). Integrity of skeletal musculature was evaluated using muscle-specific creatine kinase enzyme (CK - Table 6) whose values were within physiological range in all groups $(<4.2 \mu \mathrm{kat} / \mathrm{l}$; KRAFT - DÜRR, 1999). These results ruled out possible problems of nutritional myopathy or causes of lying down after parturition.

The results of rumen fluid examinations are stated in Table 7 - shown there are selected parameters of rumen profile of dairy cows. Distribution of volatile fatty acids is described in Table 8. No animal showed any significant disorder of ruminal digestion; $\mathrm{pH}$ levels were always in physiological range (6.2 - 7.0; VRZGULA et al., 1990) and concentration of volatile fatty acids corresponded with a good rate of ruminal digestion $(80-120$ mmol/l; VRZGULA et al., 1990). Infusoria counts were relatively high in all groups (300 - 500.10 ${ }^{3} \cdot \mathrm{ml}^{-1}$; VRZGULA et al., 1990). Similar to MUSTAFA et al. (1998) and BARTSCH and VALENTINE (1986) no significant effect of the pea diet was observed on VFA production. BARTSCH and VALENTINE compared peas with a barley diet. In their experiment the relative proportions of VFA in both types of diets were similar, except for a higher concentration of butyric acid in groups fed the peas (BARTSCH and VALENTINE, 1986). Unlike barley, peas stabilize ruminal digestion and thus improve ruminal fermentation. Starches contained in peas degrade more slowly than barley. Therefore, peas do not cause a steep decrease in ruminal fluid $\mathrm{pH}$ and do not limit the cellulolytic processes (VALENTINE and BARTSCH, 1987; CORBETT et al., 1995).

Table 4

Selected nitrogen metabolism parameters in dairy cows from control group $(C, n=8)$ and experimental groups $(G, n=8 ; G U, n=$ $8 ; \mathrm{Z}, \mathrm{n}=8$ ) as measured during the study.

(Ausgewählte Parameter des Stickstoff Metabolismus der Milchkühe aus der Kontrollgruppe $(\mathrm{K}, \mathrm{n}=8)$ und den Experimentgruppen ( $\mathrm{G}, \mathrm{n}=8$; $\mathrm{GU}, \mathrm{n}=8 ; \mathrm{Z}, \mathrm{n}=8$ ) während des Experimentzeitraums).

\begin{tabular}{|c|c|c|c|c|c|}
\hline & & Beginning & 4 weeks & 8 weeks & 12 weeks \\
\hline & $\mathrm{Z}$ & $76.99 \pm 5.25$ & $82.21 \pm 3.57$ & $82.24 \pm 3.80$ & $84.53 \pm 5.53$ \\
\hline TP & G & $74.75 \pm 8.92$ & $81.75 \pm 6.86$ & $83.06 \pm 9.72$ & $81.97 \pm 6.95$ \\
\hline \multirow{2}{*}{$\left(\mathrm{g} . \mathrm{l}^{-1}\right)$} & GU & $76.94 \pm 7.63$ & $83.63 \pm 6.98$ & $82.38 \pm 5.45$ & $82.14 \pm 4.69$ \\
\hline & $\mathrm{C}$ & $78.25 \pm 6.65$ & $83.31 \pm 6.61$ & $82.28 \pm 5.53$ & $83.64 \pm 7.49$ \\
\hline \multirow{4}{*}{$\begin{array}{l}\mathrm{U} \\
\left(\mathrm{mmol} . \mathrm{l}^{-1}\right)\end{array}$} & Z & $5.50 \pm 1.24$ & $6.12 \pm 1.10^{\text {bbcc }}$ & $4.84 \pm 0.69$ & $5.06 \pm 1.01^{\mathrm{abc}}$ \\
\hline & G & $4.66 \pm 0.76$ & $5.29 \pm 1.53$ & $4.22 \pm 0.59$ & $4.00 \pm 0.55^{\mathrm{a}}$ \\
\hline & GU & $4.94 \pm 0.64$ & $4.24 \pm 0.89^{\mathrm{bb}}$ & $4.21 \pm 0.84$ & $4.02 \pm 0.60^{b}$ \\
\hline & $\mathrm{C}$ & $4.71 \pm 0.55$ & $3.85 \pm 1.00^{\mathrm{cc}}$ & $4.41 \pm 0.50$ & $4.00 \pm 0.82^{c}$ \\
\hline
\end{tabular}

Significant differences between groups

$\mathrm{p} \leq 0.05 \quad{ }^{\mathrm{a}} \mathrm{Z}: \mathrm{G} ;{ }^{\mathrm{b}} \mathrm{Z}: \mathrm{GU} ;{ }^{\mathrm{c}} \mathrm{Z}: \mathrm{C}$

$\mathrm{p} \leq 0.01 \quad{ }^{\mathrm{bb}} \mathrm{Z}: \mathrm{GU} ;{ }^{\mathrm{cc}} \mathrm{Z}: \mathrm{C}$ 
Table 5

Selected energy metabolism parameters in dairy cows from control group $(C, n=8)$ and experimental groups $(G, n=8 ; G U, n=$ $8 ; \mathrm{Z}, \mathrm{n}=8$ ) as measured during the study.

(Ausgewählte Parameter des energetischen Metabolismus der Milchkühe aus der Kontrollgruppe $(\mathrm{K}, \mathrm{n}=8)$ und den Experimentgruppen ( $\mathrm{G}, \mathrm{n}=8$; $\mathrm{GU}, \mathrm{n}=8 ; \mathrm{Z}, \mathrm{n}=8$ ) während des Experimentzeitraums).

\begin{tabular}{|c|c|c|c|c|c|}
\hline & & beginning & 4 weeks & 8 weeks & 12 weeks \\
\hline \multirow{4}{*}{$\begin{array}{l}\text { Glu } \\
\left(\mathrm{mmol.} .^{-1}\right)\end{array}$} & $\mathrm{Z}$ & $3.10 \pm 0.29$ & $3.20 \pm 0.49$ & $3.00 \pm 0.46$ & $3.36 \pm 0.37$ \\
\hline & G & $3.35 \pm 0.38$ & $3.50 \pm 0.41$ & $3.35 \pm 0.40$ & $3.44 \pm 0.28$ \\
\hline & GU & $2.98 \pm 0.32^{f}$ & $3.64 \pm 0.56$ & $3.31 \pm 0.51$ & $3.35 \pm 0.23$ \\
\hline & $\mathrm{C}$ & $3.42 \pm 0.28^{f}$ & $3.61 \pm 0.24$ & $3.38 \pm 0.41$ & $3.46 \pm 0.20$ \\
\hline \multirow{4}{*}{$\begin{array}{l}\text { TG } \\
\left(\mathrm{mmol.} .^{-1}\right)\end{array}$} & Z & $0.16 \pm 0.08$ & $0.14 \pm 0.05$ & $0.22 \pm 0.06$ & $0.34 \pm 0.16$ \\
\hline & G & $0.13 \pm 0.05$ & $0.17 \pm 0.04$ & $0.20 \pm 0.07$ & $0.31 \pm 0.16$ \\
\hline & GU & $0.12 \pm 0.04$ & $0.16 \pm 0.03$ & $0.22 \pm 0.05$ & $0.36 \pm 0.12$ \\
\hline & $\mathrm{C}$ & $0.14 \pm 0.06$ & $0.15 \pm 0.03$ & $0.22 \pm 0.05$ & $0.36 \pm 0.14$ \\
\hline \multirow{4}{*}{$\begin{array}{l}\text { NEFA } \\
\left(\mathrm{mmol.}^{-1}\right)\end{array}$} & Z & $0.19 \pm 0.07$ & $0.19 \pm 0.02^{c}$ & $0.20 \pm 0.04$ & $0.23 \pm 0.10$ \\
\hline & G & $0.29 \pm 0.17$ & $0.36 \pm 0.41$ & $0.19 \pm 0.02$ & $0.20 \pm 0.05$ \\
\hline & $\mathrm{GU}$ & $0.24 \pm 0.13$ & $0.25 \pm 0.08$ & $0.23 \pm 0.12$ & $0.21 \pm 0.05$ \\
\hline & $\mathrm{C}$ & $0.19 \pm 0.08$ & $0.22 \pm 0.03^{c}$ & $0.20 \pm 0.02$ & $0.30 \pm 0.14$ \\
\hline \multirow{4}{*}{$\begin{array}{l}\text { BHB } \\
\left(\mathrm{mmol.}^{-1}\right)\end{array}$} & $\mathrm{Z}$ & $0.71 \pm 0.22$ & $0.86 \pm 0.24^{c}$ & $0.73 \pm 0.15$ & $0.59 \pm 0.15$ \\
\hline & G & $0.65 \pm 0.20$ & $0.69 \pm 0.20$ & $0.60 \pm 0.11$ & $0.62 \pm 0.14$ \\
\hline & GU & $0.72 \pm 0.15$ & $0.69 \pm 0.12$ & $0.61 \pm 0.10$ & $0.68 \pm 0.15$ \\
\hline & $\mathrm{C}$ & $0.67 \pm 0.24$ & $0.65 \pm 0.10^{\mathrm{C}}$ & $0.73 \pm 0.23$ & $0.75 \pm 0.35$ \\
\hline
\end{tabular}

Significant differences between groups

$\mathrm{p} \leq 0.05{ }^{\mathrm{a}} \mathrm{Z}: \mathrm{G} ;{ }^{\mathrm{b}} \mathrm{Z}: \mathrm{GU} ;{ }^{\mathrm{c}} \mathrm{Z}: \mathrm{C} ;{ }^{\mathrm{d}} \mathrm{G}: \mathrm{GU} ;{ }^{\mathrm{e}} \mathrm{G}: \mathrm{C} ;{ }^{\mathrm{f}} \mathrm{GU}: \mathrm{C}$

$\mathrm{p} \leq 0.01 \quad{ }^{\mathrm{dd}} \mathrm{G}: \mathrm{GU} ;{ }^{\mathrm{ff}} \mathrm{GU}: \mathrm{C}$

Table 6

Selected parameters of enzymatic profile and a total bilirubin values in dairy cows of control group $(\mathrm{C}, \mathrm{n}=8)$ and experimental groups ( $\mathrm{G}, \mathrm{n}=8$; $\mathrm{GU}, \mathrm{n}=8 ; \mathrm{Z}, \mathrm{n}=8$ ) as measured during the study.

(Ausgewählte Parameter des Enzymsprofils und des Gesamtbilirubins der Milchkühe aus der Kontrollgruppe $(\mathrm{K}, \mathrm{n}=8)$ und den Experimentgruppen (G, n = 8; GU, n = 8; Z, n = 8) während des Experimentzeitraums.

\begin{tabular}{|c|c|c|c|c|c|}
\hline & & Beginning & 4 weeks & 8 weeks & 12 weeks \\
\hline \multirow{4}{*}{$\begin{array}{l}\text { BIL } \\
\left(\mu \mathrm{mol} .1^{-1}\right)\end{array}$} & $\mathrm{Z}$ & $5.81 \pm 0.73$ & $4.09 \pm 1.33$ & $3.40 \pm 0.54$ & $4.01 \pm 0.78$ \\
\hline & G & $6.14 \pm 0.67$ & $5.30 \pm 2.37$ & $3.44 \pm 0.58$ & $3.61 \pm 0.41$ \\
\hline & GU & $6.06 \pm 0.61$ & $4.46 \pm 1.37$ & $3.55 \pm 0.45$ & $3.79 \pm 0.46$ \\
\hline & $\mathrm{C}$ & $6.14 \pm 0.55$ & $4.31 \pm 0.93$ & $3.81 \pm 0.31$ & $4.40 \pm 1.23$ \\
\hline \multirow{4}{*}{$\begin{array}{l}\text { GMT } \\
\left(\mu \text { kat. }^{-1}\right)\end{array}$} & Z & $0.47 \pm 0.15$ & $0.54 \pm 0.15$ & $0.54 \pm 0.11$ & $0.61 \pm 0.10$ \\
\hline & G & $0.47 \pm 0.07$ & $0.54 \pm 0.08$ & $0.55 \pm 0.14$ & $0.62 \pm 0.14$ \\
\hline & GU & $0.42 \pm 0.06$ & $0.52 \pm 0.11$ & $0.50 \pm 0.12$ & $0.60 \pm 0.19$ \\
\hline & $\mathrm{C}$ & $0.48 \pm 0.12$ & $0.51 \pm 0.09$ & $0.49 \pm 0.07$ & $0.56 \pm 0.08$ \\
\hline \multirow{4}{*}{$\begin{array}{l}\text { CK } \\
\left(\mu k \text { kat. } .^{-1}\right)\end{array}$} & Z & $1.53 \pm 0.88$ & $1.88 \pm 0.27$ & $1.31 \pm 0.34$ & $1.55 \pm 1.03$ \\
\hline & $\mathrm{G}$ & $1.33 \pm 0.29$ & $1.86 \pm 0.50$ & $1.43 \pm 0.51$ & $1.39 \pm 0.45$ \\
\hline & GU & $2.31 \pm 1.02$ & $2.46 \pm 0.91$ & $1.79 \pm 0.63$ & $1.69 \pm 0.72$ \\
\hline & $\mathrm{C}$ & $1.32 \pm 0.35$ & $2.02 \pm 0.56$ & $1.53 \pm 0.48$ & $2.43 \pm 2.13$ \\
\hline
\end{tabular}

Significant differences between groups $\mathrm{p} \leq 0.05{ }^{\mathrm{d}} \mathrm{G}: \mathrm{GU}$ 
Table 7

Selected parameters of rumen profile in dairy cows of control group $(C, n=8)$ and experimental groups $(G, n=8 ; G U, n=8 ; Z, n$ $=8$ ) as measured during the study

(Ausgewählte Parameter des Pansenprofils der Milchkühe aus der Kontrollgruppe $(K, \mathrm{n}=8)$ und den Experimentgruppen $(\mathrm{G}$, $\mathrm{n}=$ 8; GU, n = 8; Z, n = 8) während des Experimentzeitraums)

\begin{tabular}{|c|c|c|c|c|c|}
\hline & & Beginning & 4 weeks & 8 weeks & 12 weeks \\
\hline \multirow{4}{*}{$\mathrm{pH}$} & $\mathrm{Z}$ & $6.67 \pm 0.17$ & $6.54 \pm 0.17$ & $6.56 \pm 0.20$ & $6.67 \pm 0.33$ \\
\hline & G & $6.54 \pm 0.31$ & $6.42 \pm 0.18$ & $6.58 \pm 0.22$ & $6.70 \pm 0.35$ \\
\hline & GU & $6.49 \pm 0.19$ & $6.60 \pm 0.21$ & $6.54 \pm 0.19$ & $6.66 \pm 0.22$ \\
\hline & $\mathrm{C}$ & $6.52 \pm 0.15$ & $6.57 \pm 0.15$ & $6.57 \pm 0.18$ & $6.64 \pm 0.30$ \\
\hline \multirow{4}{*}{$\begin{array}{l}\text { Total } \\
\text { (titr. j.) }\end{array}$} & $\mathrm{Z}$ & $18.33 \pm 2.26$ & $22.74 \pm 2.69$ & $20.70 \pm 4.35$ & $19.03 \pm 5.22$ \\
\hline & G & $20.38 \pm 5.53$ & $24.45 \pm 4.27$ & $21.35 \pm 5.64$ & $18.91 \pm 4.09$ \\
\hline & GU & $20.13 \pm 3.76$ & $19.81 \pm 4.26$ & $24.26 \pm 8.82$ & $18.40 \pm 3.77$ \\
\hline & $\mathrm{C}$ & $20.55 \pm 2.49$ & $21.01 \pm 2.88$ & $23.20 \pm 2.82$ & $19.18 \pm 4.82$ \\
\hline \multirow{4}{*}{$\begin{array}{l}\text { Infusoria } \\
\text { quantity } \\
\left(.10^{-9} .1\right)\end{array}$} & $\mathrm{Z}$ & $344.0 \pm 120.5$ & $362.0 \pm 111.6^{\mathrm{a}}$ & $543.0 \pm 164.9^{c}$ & $392.0 \pm 154.9$ \\
\hline & G & $403.0 \pm 151.5$ & $536.0 \pm 145.9^{\text {ad }}$ & $544.0 \pm 163.0^{e}$ & $452.6 \pm 81.1$ \\
\hline & GU & $438.0 \pm 96.2$ & $372.0 \pm 87.3^{d}$ & $452.0 \pm 153.1$ & $414.0 \pm 122.9$ \\
\hline & $\mathrm{C}$ & $415.0 \pm 138.5$ & $424.0 \pm 71.2$ & $385.0 \pm 100.5^{\text {ce }}$ & $310.0 \pm 75.7$ \\
\hline \multirow{4}{*}{$\begin{array}{l}\text { Ammonia } \\
\left(\mathrm{mmol} . \mathrm{l}^{-1}\right)\end{array}$} & $\mathrm{Z}$ & $4.03 \pm 1.54$ & $6.23 \pm 2.18^{\text {bbcc }}$ & $5.34 \pm 2.28^{b}$ & $4.64 \pm 0.87$ \\
\hline & $\mathrm{G}$ & $3.79 \pm 1.64$ & $5.06 \pm 2.28$ & $3.35 \pm 1.65$ & $5.31 \pm 4.44$ \\
\hline & GU & $3.90 \pm 1.45$ & $3.03 \pm 1.19^{b b}$ & $3.15 \pm 0.91^{b}$ & $4.84 \pm 3.49$ \\
\hline & $\mathrm{C}$ & $3.43 \pm 1.35$ & $2.93 \pm 1.57^{\mathrm{cc}}$ & $2.78 \pm 0.65$ & $4.45 \pm 2.55$ \\
\hline \multirow{4}{*}{$\begin{array}{l}\text { VFA } \\
\left(\mathrm{mmol}^{-1} \mathrm{l}^{-1}\right)\end{array}$} & $\mathrm{Z}$ & $112.6 \pm 10.4$ & $132.0 \pm 17.8$ & $122.8 \pm 14.4$ & $98.8 \pm 21.0$ \\
\hline & G & $115.3 \pm 12.8$ & $129.1 \pm 14.2$ & $118.8 \pm 13.5$ & $105.7 \pm 20.8$ \\
\hline & GU & $120.2 \pm 11.1$ & $117.3 \pm 15.9$ & $117.3 \pm 13.2$ & $110.3 \pm 13.0$ \\
\hline & $\mathrm{C}$ & $118.3 \pm 9.2$ & $126.3 \pm 12.8$ & $112.2 \pm 9.1$ & $109.1 \pm 19.5$ \\
\hline
\end{tabular}

Significant differences between groups

$\mathrm{p} \leq 0.05{ }^{\mathrm{a}} \mathrm{Z}: \mathrm{G} ;{ }^{\mathrm{b}} \mathrm{Z}: \mathrm{GU} ;{ }^{\mathrm{c}} \mathrm{Z}: \mathrm{C} ;{ }^{\mathrm{d}} \mathrm{G}: \mathrm{GU} ;{ }^{\mathrm{e}} \mathrm{G}: \mathrm{C} ;{ }^{\mathrm{f}} \mathrm{GU}: \mathrm{C}$

$\mathrm{p} \leq 0.01 \quad{ }^{\mathrm{bb}} \mathrm{Z}: \mathrm{GU} ;{ }^{\mathrm{cc}} \mathrm{Z}: \mathrm{C}$

Evaluation of milk production

Milk performance

The evaluation of milk production in individual groups during the study is stated in Tables 9 and 10. In the course of 90 day lactation, the daily milk yield in all groups showed similar decreasing tendencies that correspond with physiological lactation. Significant difference was observed only at the end of the study between groups $\mathrm{Z}$ and $\mathrm{G}$ (cows from group $\mathrm{Z}$ showed a significantly higher milk yield). However, no significant differences were found between groups in the amount of daily milk yield decrease as measured in individual dairy cows (assuming that the initial milk yield was $100 \%$ ). Groups Z, GU and C showed similar decrease of daily milk yield (85 - $88 \%$ ). Cows from group $\mathrm{G}$ showed higher decrease (77 \%). There were relatively big differences between individual cows from groups $\mathrm{G}$ and $\mathrm{GU}$. There is no conclusive evidence as to whether the noticeable decrease in group $\mathrm{G}$ was caused by higher anti-nutritional content of Gotik cultivar. Results of trials investigating the effect of milk production of feeding rations containing peas vary. CORBETT et al. (1995) observed increased milk production after adding peas to feeding ration in the early lactation period of first-calf heifers. 
Table 8

Distribution of volatile fatty acids in rumen fluid in dairy cows of control group $(C, n=8)$ and experimental groups $(G, n=8$; $\mathrm{GU}, \mathrm{n}=8 ; \mathrm{Z}, \mathrm{n}=8$ ) as measured during the study.

(Zusammensetzung der Ketonkörper im Pansensaft der Milchkühe aus der Kontrollgruppe $(\mathrm{K}, \mathrm{n}=8)$ und den Experimentgruppen ( $\mathrm{G}, \mathrm{n}=8 ; \mathrm{GU}, \mathrm{n}=8 ; \mathrm{Z}, \mathrm{n}=8$ ) während des Experimentzeitraums.

\begin{tabular}{|c|c|c|c|c|c|}
\hline & & Beginning & 4 weeks & 8 weeks & 12 weeks \\
\hline \multirow{4}{*}{ Acetic acid (mol \%) } & $\mathrm{Z}$ & $60.03 \pm 3.16$ & $59.63 \pm 2.40$ & $59.73 \pm 3.33$ & $52.78 \pm 18.49$ \\
\hline & G & $59.25 \pm 4.04$ & $61.23 \pm 3.87$ & $59.96 \pm 3.16$ & $59.74 \pm 3.89$ \\
\hline & GU & $60.40 \pm 2.39$ & $59.91 \pm 1.56$ & $60.24 \pm 1.94$ & $60.04 \pm 2.21$ \\
\hline & $\mathrm{C}$ & $61.38 \pm 2.12$ & $61.23 \pm 1.85$ & $60.59 \pm 1.59$ & $59.70 \pm 3.89$ \\
\hline \multirow{4}{*}{$\begin{array}{l}\text { Propionic acid } \\
\text { (mol \%) }\end{array}$} & $\mathrm{Z}$ & $19.91 \pm 3.01$ & $19.81 \pm 2.04$ & $19.95 \pm 3.19$ & $22.06 \pm 3.21$ \\
\hline & G & $19.80 \pm 4.43$ & $23.75 \pm 13.80$ & $20.20 \pm 3.36$ & $21.27 \pm 3.50$ \\
\hline & GU & $19.49 \pm 2.26$ & $20.54 \pm 2.58$ & $20.59 \pm 2.75$ & $20.80 \pm 1.42$ \\
\hline & $\mathrm{C}$ & $19.23 \pm 1.66$ & $19.88 \pm 1.21$ & $20.74 \pm 2.10$ & $20.64 \pm 2.34$ \\
\hline \multirow{4}{*}{$\begin{array}{l}\text { Iso-butyric acid } \\
\text { (mol \%) }\end{array}$} & $\mathrm{Z}$ & $0.96 \pm 0.30$ & $1.01 \pm 0.19$ & $1.04 \pm 0.39^{\mathrm{bc}}$ & $0.88 \pm 0.20$ \\
\hline & G & $0.85 \pm 0.23$ & $1.00 \pm 0.21$ & $0.71 \pm 0.13$ & $0.74 \pm 0.15$ \\
\hline & GU & $0.78 \pm 0.16$ & $0.85 \pm 0.26$ & $0.60 \pm 0.13^{b}$ & $0.70 \pm 0.11$ \\
\hline & $\mathrm{C}$ & $0.78 \pm 0.13$ & $0.88 \pm 1.21$ & $0.64 \pm 0.05^{c}$ & $0.69 \pm 0.14$ \\
\hline \multirow{4}{*}{$\begin{array}{l}\text { N-butyric acid } \\
\text { (mol \%) }\end{array}$} & Z & $16.60 \pm 2.23$ & $16.86 \pm 1.38$ & $16.94 \pm 1.55$ & $14.25 \pm 0.88^{\mathrm{ab}}$ \\
\hline & $\mathrm{G}$ & $17.46 \pm 3.45$ & $15.29 \pm 1.91$ & $16.34 \pm 1.10$ & $15.51 \pm 0.89^{\mathrm{a}}$ \\
\hline & GU & $17.05 \pm 1.53$ & $16.34 \pm 1.81$ & $16.09 \pm 1.12$ & $15.96 \pm 1.90^{b}$ \\
\hline & $\mathrm{C}$ & $16.49 \pm 1.30$ & $15.51 \pm 1.27$ & $15.63 \pm 1.33$ & $16.66 \pm 2.88$ \\
\hline
\end{tabular}

Significant differences between groups

$\mathrm{p} \leq 0.05 \quad{ }^{\mathrm{a}} \mathrm{Z}: \mathrm{G} ;{ }^{\mathrm{b}} \mathrm{Z}: \mathrm{GU} ;{ }^{\mathrm{c}} \mathrm{Z}: \mathrm{C} ;{ }^{\mathrm{d}} \mathrm{G}: \mathrm{GU} ;{ }^{\mathrm{e}} \mathrm{G}: \mathrm{C} ;{ }^{\mathrm{f}} \mathrm{GU}: \mathrm{C}$

$\mathrm{p} \leq 0.01 \quad{ }^{\text {aa }} \mathrm{Z}: \mathrm{G} ;{ }^{\mathrm{bb}} \mathrm{Z}: \mathrm{GU} ;{ }^{\mathrm{cc}} \mathrm{Z}: \mathrm{C} ;{ }^{\mathrm{dd}} \mathrm{G}: \mathrm{GU} ;{ }^{\text {ee }} \mathrm{G}: \mathrm{C} ;{ }^{\mathrm{ff}} \mathrm{GU}: \mathrm{C}$

Moreover, they reported an increase of fat content in milk from early to mid lactation stages. Nevertheless, KHASAN et al. (1989) and KHORASANI et al. (1992) reported decreased milk yield in high producing dairy cattle after replacing soybeans with pea seeds. This decrease may have been caused by a lower content of undegradable protein in peas in comparison to soya. No milk yield decrease was noted in late lactation stage (KHORASANI et al., 2001). Some researchers (HODEN et al., 1992; MESSMAN et al., 1992) recommend using peas as a source of protein only when low levels of undegradable protein are needed. This applies particularly to cows in late lactation stage or to lowproducing cattle. However, others (WARD et al., 1989; VALENTINE and BARTSCH, 1990; JUTZ and LEITGEB, 1989) believe that peas can be used as the only source of protein even in high-producing dairy cattle. Another possibility is to use heat-treated peas that replace soya without decreasing milk production (PETIT et al., 1997). 
Table 9

Overall production of milk, fat, protein and lactose in individual groups (Z - Zekon, n = 8; G - Gotik n = 8; GU - Gotik treated, $n$ $=8 ; \mathrm{C}-$ control, $\mathrm{n}=8$ ) as measured during the study.

(Gesamtproduktion der Milch, des Fettes und des Proteins bei den einzelnen Gruppen (Z - Zekon, G- Gotik, GU - modifiziertes Gotik, K - Kontrollgruppe) während des beobachteten Zeitraums).

\begin{tabular}{|c|c|c|}
\hline & & $\begin{array}{l}\text { Milk yield for } 90 \text { days of experiment } \\
\text { (kg) }\end{array}$ \\
\hline \multirow{4}{*}{ Milk yield } & $\mathrm{Z}$ & $2759 \pm 273$ \\
\hline & G & $2431 \pm 308$ \\
\hline & GU & $2565 \pm 311$ \\
\hline & $\mathrm{C}$ & $2598 \pm 274$ \\
\hline \multirow{4}{*}{ Fat } & $\mathrm{Z}$ & $108.3 \pm 18.2$ \\
\hline & G & $94.8 \pm 10.2$ \\
\hline & GU & $99.2 \pm 14.5$ \\
\hline & $\mathrm{C}$ & $94.4 \pm 12.3$ \\
\hline \multirow{4}{*}{ Protein } & $\mathrm{Z}$ & $93.4 \pm 11.8^{\mathrm{a}}$ \\
\hline & G & $78.4 \pm 7.2^{\mathrm{a}}$ \\
\hline & GU & $84.8 \pm 10.8$ \\
\hline & $\mathrm{C}$ & $83.8 \pm 11.3$ \\
\hline \multirow{4}{*}{ Lactose } & $\mathrm{Z}$ & $134.8 \pm 12.8^{\mathrm{a}}$ \\
\hline & G & $115.9 \pm 15.2^{\mathrm{a}}$ \\
\hline & GU & $125.8 \pm 15.5$ \\
\hline & $\mathrm{C}$ & $125.0 \pm 12.3$ \\
\hline
\end{tabular}

Significant differences between groups

$\mathrm{p} \leq 0.05{ }^{\mathrm{a}} \mathrm{Z}: \mathrm{G} ;{ }^{\mathrm{b}} \mathrm{Z}: \mathrm{GU} ;{ }^{\mathrm{c}} \mathrm{Z}: \mathrm{C} ;{ }^{\mathrm{d}} \mathrm{G}: \mathrm{GU} ;{ }^{\mathrm{e}} \mathrm{G}: \mathrm{C} ;{ }^{\mathrm{f}} \mathrm{GU}: \mathrm{C}$

Milk composition

Significant differences in milk composition between groups were observed only during the second month of the study (Table 10). Group GU showed higher fat concentrations than the control group. Also, group $\mathrm{Z}$ showed higher protein concentrations than the control group. As these differences were not noted during other months of the study, it is supposed that they were not caused by the feeding mixture. Significant differences in the overall production of milk, fat, protein and lactose (Table 9) were observed only between groups $\mathrm{Z}$ and $\mathrm{G}$ (protein and lactose production was significantly higher in group Z). These differences were caused mostly by higher milk production, but also by protein and lactose concentrations in milk, which were insignificantly higher in group Z. Both groups showed similar concentration of fat in milk. The quantity of milk yield between the start and end of the experiment reached its highest values in group Z (85.1 $\pm .3 \%$ ); in groups GU a C in ranged from $83.5 \pm 13.8$ to $84.6 \pm 4.2$ and the lowest values were found in group $\mathrm{G}(78.6 \pm 14.4 \%)$.

Other researchers (CORBETT et al., 1995; MESSMAN et al., 1992) have reported increased concentrations of milk fat in cows fed the peas during all lactation stages compared to cows fed the soya. They believe that higher milk fat levels are caused by complex, non-structural, low-degradable saccharides contained in peas. Like these researchers, there was no observed effect of peas on production of milk protein. 
Table 10

Milk composition and milk production in individual groups ( $\mathrm{Z}$ - Zekon, $\mathrm{n}=8$; $\mathrm{G}$ - Gotik $\mathrm{n}=8$; $\mathrm{GU}$ - Gotik treated, $\mathrm{n}=8$; $\mathrm{C}-$ control, $\mathrm{n}=8$ ) as measured during the study.

(Milchzusammensetzung und Milchproduktion bei den einzelnen Gruppen (Z - Zekon, G- Gotik, GU - Gotik modifiziert, K Kontrollgruppe) während des Experimentzeitraums.

\begin{tabular}{|c|c|c|c|c|}
\hline & & 4 weeks & 8 weeks & 12 weeks \\
\hline \multirow{4}{*}{$\begin{array}{l}\text { Fat } \\
(\%)\end{array}$} & $\mathrm{Z}$ & $3.96 \pm 0.62$ & $3.85 \pm 0.32$ & $3.91 \pm 0.35$ \\
\hline & G & $3.84 \pm 0.70$ & $3.97 \pm 0.61$ & $4.01 \pm 0.65$ \\
\hline & GU & $3.81 \pm 0.24$ & $4.06 \pm 0.20^{\mathrm{f}}$ & $3.71 \pm 0.29$ \\
\hline & $\mathrm{C}$ & $3.59 \pm 0.47$ & $3.47 \pm 0.18^{f}$ & $3.83 \pm 0.26$ \\
\hline \multirow{4}{*}{$\begin{array}{l}\text { Protein } \\
\text { (\%) }\end{array}$} & $\mathrm{Z}$ & $3.34 \pm 0.29$ & $3.41 \pm 0.20^{c}$ & $3.57 \pm 0.26$ \\
\hline & G & $3.16 \pm 0.40$ & $3.26 \pm 0.32$ & $3.36 \pm 0.25$ \\
\hline & $\mathrm{GU}$ & $3.22 \pm 0.24$ & $3.26 \pm 0.16$ & $3.48 \pm 0.14$ \\
\hline & $\mathrm{C}$ & $3.21 \pm 0.33$ & $3.12 \pm 0.12^{\mathrm{c}}$ & $3.35 \pm 0.21$ \\
\hline \multirow{4}{*}{$\begin{array}{l}\text { Milk sugar } \\
\text { (\%) }\end{array}$} & $\mathrm{Z}$ & $4.91 \pm 0.14$ & $4.89 \pm 0.11$ & $4.84 \pm 0.13$ \\
\hline & G & $4.81 \pm 0.20$ & $4.79 \pm 0.13$ & $4.76 \pm 0.13$ \\
\hline & $\mathrm{GU}$ & $4.98 \pm 0.16$ & $4.90 \pm 0.09$ & $4.81 \pm 0.16$ \\
\hline & $\mathrm{C}$ & $4.89 \pm 0.23$ & $4.81 \pm 0.18$ & $4.75 \pm 0.19$ \\
\hline \multirow{4}{*}{$\begin{array}{l}\text { Daily } \\
\text { yield } \\
\text { (l) }\end{array}$} & $\mathrm{Z}$ & $32.4 \pm 2.5$ & $30.9 \pm 3.9$ & $28.6 \pm 3.7^{\mathrm{a}}$ \\
\hline & $\mathrm{G}$ & $30.3 \pm 3.3$ & $27.3 \pm 5.0$ & $23.4 \pm 3.1^{\mathrm{a}}$ \\
\hline & $\mathrm{GU}$ & $31.1 \pm 4.8$ & $27.7 \pm 2.9$ & $26.7 \pm 3.7$ \\
\hline & $\mathrm{C}$ & $30.6 \pm 3.3$ & $29.1 \pm 3.6$ & $26.9 \pm 2.7$ \\
\hline
\end{tabular}

Significant differences between groups

$\mathrm{p} \leq 0.05 \quad{ }^{\mathrm{a}} \mathrm{Z}: \mathrm{G} ;{ }^{\mathrm{b}} \mathrm{Z}: \mathrm{GU} ;{ }^{\mathrm{c}} \mathrm{Z}: \mathrm{C} ;{ }^{\mathrm{d}} \mathrm{G}: \mathrm{GU} ;{ }^{\mathrm{e}} \mathrm{G}: \mathrm{C} ;{ }^{\mathrm{f}} \mathrm{GU}: \mathrm{C}$

On the basis of the present trial, peas can be used as an apposite alternative source of proteins and energy in the diet of dairy cattle, fully replacing imported feedstuffs such as soya. In most cases, the differences between individual experimental groups were not significant. Although there was noted a slightly better production results in cows fed the Zekon cultivar (low anti-nutritional content) and, conversely, worse production results (especially milk parameters) in group fed the Gotik cultivar (high anti-nutritional content), it cannot be univocally said that feeding the Gotik cultivar is in any way a risk. These results indicate that while using technologically treated peas may not be economical, they show excellent anti-nutritional values. The present study proves that anti-nutritional substances contained in native peas do not have a seriously negative impact for high-producing dairy cows. Nevertheless, the advantage of treated peas can be seen in their higher content of crude protein undegradable in the rumen.

\section{Acknowledgments}

This work was supported by the Grant Agency of the Ministry of Agriculture (Grant No. GF 3070). 


\section{References}

BARTSCH, B. D.; VALENTINE, S.C.:

Grain legumes in dairy cow nutrition. Proc. Aust. Soc. Anim. Prod., 16 (1986), 32-34

BENCHAAR, C.; VERNAY, M.; BAYOURTHE, C.; MONCOULON, R.:

Effects of extrusion of whole horse beans on protein digestion and amino acid absorption in dairy cows. J. Dairy Sci., 77 (1994), 1360-1371

CORBETT, R.R.; OKINE, E.K.; GOONEWARDENE, L.A.:

Effects of feeding peas to high-producing dairy cows. Can. J. Anim. Sci., 75 (1995), 625-629

DAVEBY, Y. D.; AMAN, P.:

Chemical composition of certain dehulled legume seeds and their hulls with special reference to carbohydrates. Swed. J. Agr. Res., 23 (1993), 133-139

DVORAK, R.; PECHOVA , A.; PAVLATA, L.; FILÍPEK, J.; DOSTALOVA, J.; REBLOVA, Z.; KLEJDUS, B.; POUL, J.:

Reduction in the content of antinutritional substances in pea seeds (Pisum sativum L.) by different treatments. Czech J. Anim. Sci., 50 (2005), 519-527

GABEL, M.; VOIGT, J.:

Fütterung der Hochleistungskuh aus stofflicher und energetischer Sicht. Arch. Tierz. 43 (2000) Sonderheft, $62-70$

GOELEMA, J. O.; SPREUWENBERGER, M. A. M.; HOF, G.; POEL, A. F. B.; TAMMINGA, S.:

Effect of pressure toasting on the rumen degradability and intestinal digestibility of whole and broken peas, lupins and faba beans and a mixture of these feedstuffs. Anim. Feed Sci. Tech., 76 (1998), 35-50

HODEN, A.; DELABY, L.; MARGUIS, B.: JANS, F.: Pea protein for use a single concentrate for dairy cows. Prod. Anim., 5 (1992), 37-42

Use of barley and pea concentrate mixture in dairy cow feed trials. Revue suisse d'agriculture, 25 (1993), 369-371

JUTZ T.C., LEITGEB R.:

The use of horse beans (Vicia faba L.) and peas (Pisum sativum L.) in feeding of cows. Original Title Einsatz von Ackerbohnen (Vicia faba L.) and Saaterbsen (Pisum sativum L.) in der Milchviehfutterung. Wirtschaftseigene-Futter, 35 (1989), 149-161.

KALAITZAKIS, E.; ROUBIES, N.; PANOUSIS, N.; POURLIOTIS, K; KALDRYMIDOU, E.; KARATZIAH.: Clinicopathologic Evaluation of Hepatic Lipidosis in Periparturient Dairy Cattle. J.Vet. Intern. Med., 21 (2007), 835-845

KHASAN, A. M.; TASHEV, T. K.; TODOROV, N.A.; HASAN, A. M.:

Lucerne haylage, sunflower meal and peas as protein feeds in diets for dairy cows Zhivotnov Dni - Nauki, 26 (1989), 30-36

KHORASANI, G. R.; OKINE, E. K.; CORBETT, R .R.; KENELLY, J. J.:

Peas for dairy cattle. 71 st. Ann. Feed. Day Rep. Anim. Sci. Dep. University of Alberta, Edmonton, AB (1992), 28

KHORASANI, G.R.; OKINE, E.K.; CORBETT, R.R.:

Nutritive value of peas for lactating dairy cattle. Can. J. Anim. Sci., 81 (2001), 541-551

KRAFT, W.; DÜRR, U.M.:

Clinical ndokrinology, Skeletal musculature. Clinical Laboratory Diagnostician in Veterinary medicine (in Czech), (1999), 219; 249-250

LALÉS, J.P.:

Nutritional and Antinutritional Aspects of Soyabean and Field Pea Proteins used in Veal Calf Production: a review. Livestock Prod. Sci., 34 (1993), 181-202

LOSAND, B.; DRESCHEL,H.; MARTIN,J.; PRIEPKE,A.:

Nutzung einheimischer Eiweißpflanzen in der Fütterung. Arch. Tierz. 46 (2003) Sonderheft, 107-114

MESSMAN, M. A.; WEISS, W. P.; HENDERLONG, P. R.; SHOCKEY, W. L.:

Evaluation of pearl millet and field peas plus triticale silages for midlactation dairy cows. J. Dairy Sci., 75 (1992), 2769-2775

MUSTAFA, A. F.; MCKINNON, J. J.; CHRISTENSEN, D. A.:

Effects of Moist Heat Treatment of Crude Protein Composition and Degradability of Field Peas. Can. J. Anim. Sci., 78: (1998), 453-456 
PECHOVA, A.; ILLEK, J.; HALOUZKA, R.:

Diagnosis and Control of the Development of Hepatic Steatosis in Dairy Cows in the Postparturient Period. Acta Vet. Brno, 66 (1997), 235-243

PETIT, H. V.; RIOUX, R.; OUELLET, D. R:

Milk production and intake of lactating cows fed raw or extruded peas. J. Dairy Sci., 80 (1997), 3377-3385

REED, J. J.; LARDY, G. P.; BAUER, M. L.; GILBERY, T. C.; CATON, J. S.:

Effect of field pea level on intake, digestion, microbial efficiency, ruminal fermentation, and in situ disappearance in beef steers fed growing diets. J. Anim. Sci., 82 (2004), 2123-2130

ROTHMAIER, A.; KIRCHGESSNER, M.:

Feeding value of 2 varieties of peas (Pisum-sativum ssp sativum or round seeded peas and Pisum-sativum ssp medulare or wrinkled seeded peas) for ruminant and pigs. Agribiological research Zeitchrift fur Agrarbiologie, Agrikulturchemie, okologie, 43 (1990), 225-233

SEKINE, J.; KAMEL, H. E. M.; HISHINUMA, M.; FADEL EL - SEED, M.A.; NASIR, A.; MORITA, S.; HANADA, M.; KONDO, S.:

Effect of Protein Sources with Different Rumen Degradability in a Diet on the Efficiency of Utilization of Metabolizable Energy by Calves. Arch. Tierz., Dummerstorf 47 (2004), 325-335

STAUFENBIEL, R.; SCHRÖDER, U.; GELFERT, C-CH.; PANICKE, L.:

Body condition and metabolic stability as basis of high milk yield, reproductive performance, and general health in dairy cows. Arch. Tierz., Dummerstorf 46 (2003), 513-526

VALENTINE, S. C.; BARTSCH, B. D.:

Fermentation of hammer milled barley, lupin, pea and faba bean grain in the rumen of dairy cows. Anim. Feed. Sci. Tech., 16 (1987), 261-271

VALENTINE, S. C.; BARTSCH B. D.:

Milk production by dairy cows fed legume grains or barley grain with or without urea as supplements to a cereal hay based diet. Aust. J. Exp. Agr., 30 (1990), 7-10

VRZGULA, L.:

Interpretation of biochemical parameters. Metabolic Disorders of Farm Animals and Their Precaution (in Czech), (1990), 480-483

WARD, D.; CORBETT, R.R.; SLACK,W.; GOONEWARDENE, L.:

Field peas as protein source for lactating dairy cows. Farming For The Future Project Number 89-F023-5. Alberta Agriculture and Rural Development (1989)

Received: 2006-11-07

Accepted: 2008-01-12

Authors address

MVDr. VERONIKA MELICHAROVÁ, doc. MVDr. ALENA PECHOVÁ, CSc., prof. MVDr. RUDOLF DVOŘÁK, CSc., doc. MVDr. LEOŠ PAVLATA, PhD. and MVDr. VERONIKA LUBOJACKÁ

Clinic of Diseases of Ruminants

University of Veterinary and Pharmaceutical Sciences Brno

Faculty of Veterinary Medicine

Palackého 1/3, 61242 BRNO

CZECH REPUBLIC

email: melicharovav@vfu.cz 